\title{
UNIVERSITY OF ROME CARBON-14 DATES IV
}

\author{
M. ALESSIO, F. BELLA \\ Istituto di Fisica, Università di Roma. Istituto Nazionale di Fisica \\ Nucleare, Sezione di Roma
}

\section{F. BACHECHI and C. CORTESI}

Istituto di Geochimica, Università di Roma

The list includes age measurements carried out from December 1964 to October 1965. As in the previous list (Rome III) the samples dated. are almost all of archaeological interest and are drawn from Italian and some European and Asiatic territories.

The chemical and physical techniques and instruments used for these measurements are essentially the same as those used previously (Bella and Cortesi, 1960; Alessio, Bella and Cortesi, 1964). The same two counters are still being used and each sample is measured by both. For dating small samples a counter is used similar to the others but of smaller volume (Alessio, Allegri and Bella, 1960); its characteristics are efficient volume $0.5 \mathrm{~L}$, length of the wire $160 \mathrm{~mm}$, diam of the wire 0.05 $\mathrm{mm}$, internal diam of the counter $60 \mathrm{~mm}$, supply voltage 8,200 volts, background $2.40 \pm 0.08$ counts $/ \mathrm{min}$, counting rate for modern carbon $10.43 \pm 0.15$ counts $/ \mathrm{min}$. The errors, quoted as in Rome III, are the $1 \sigma$ statistical errors. Ages have still been calculated using Libby's half life of $5568 \pm 30$ yr with 1950 as the standard year of reference. As in Rome II and Rome III measurements, the same modern wood grown near Rome between 1949 and 1953 has been used as modern standard; recently its activity has been once again carefully checked and judged satisfactory.

\section{ACKNOWIEDGMENTS}

The authors wish to thank the Consiglio Nazionale delle Ricerche which has provided partial financial support.

\section{SAMPLE DESCRIPTIONS}

I. ARCHAEOLOGIC SAMPLES

\section{A. Italy}

\section{Caverna delle Arene Candide series}

Charcoal from Caverna delle Arene Candide deposit on southern side of Mt. Ciaprazoppa, a small promontory of Ligurian Riviera near Finale Ligure Marina $25 \mathrm{~km} \mathrm{SW}$ Savona, Liguria $\left(44^{\circ} 09^{\prime} 42^{\prime \prime} \mathrm{N}\right.$ Lat, $8^{\circ}$ 19' 34" E Long, $90 \mathrm{~m}$ above sealevel). Cave No. 34 in "Catalogo Speleologico Ligure." Coll. 1939-1950 and subm. 1957 by L. Cardini, Ist. Italiano di Paleontologia Umana. Cave is reckoned the most important prehistoric settlement in Liguria; the succession of cultures in its stratigraphy (from Upper Paleolithic to Iron Age) is fundamental to study 
the prehistory both of this region and neighbouring ones (Po Plain, Western Mediterranean, etc.). Exploration of deposit was begun by G. B. Amerano and A. Issel at end of 19th century; systematic excavation was carried out in 1939-1950 by L. Cardini and L. Bernabò Brea, Soprintendente alle Antichità della Sicilia Orientale, formerly Soprintendente alle Antichità della Liguria. From surface downward the following archaeological layers were identified: I, Iron Age, Levels 1-4; II, Bronze Age, Levels 5-8; III, Late Neolithic, Lagozza culture, Levels 9-14; IV, Middle Neolithic with square-mouthed pots (2nd phase) and quadrilobate-mouthed pots (1st phase), Levels 16-24; V, Early Neolithic with printed pottery, Levels 25-26; VI, Epipaleolithic, Epigravettian type industry; VII, Upper Paleolithic, Late Aurignacian type industry. Hearths and numerous tombs of various types have been found in Middle Neolithic strata and at bottom of Epipaleolithic level (Bernabò Brea, 1946, 1956; Cardini, 1941, 1942, 1946, 1955).

$5075 \pm 45$

R-104. Arene Candide III 3125 B.C.

Charcoal from Levels $12-13,1.60$ to $1.80 \mathrm{~m}$ below surface. Late Neolithic, Lagozza culture.

R-103. Arene Candide IV-2

$\mathbf{5 4 6 5} \pm \mathbf{5 0}$

Charcoal from Levels $16-19,1.90$ to $2.20 \mathrm{~m}$ below surface. Middle Neolithic, square-mouthed pots culture. Remains of domestic animals and scarce wild fauna.

\section{R-102. Arene Candide IV-1}

$5335 \pm 50$

Charcoal from Levels $21-24,2.45$ to $3.05 \mathrm{~m}$ below surface. Middle Neolithic, quadrilobate-mouthed pots with notched rim, 1st phase of square-mouthed pots culture. Remains of domestic animals and scarce wild fauna.

\section{R-101. Arene Candide V}

$6220 \pm 55$

Charcoal from Levels 25-26, 3.05 to $3.30 \mathrm{~m}$ below surface. Early Neolithic, printed pottery together with remains of domestic and wild animals, numerous shells of marine molluscs, food refuse.

\section{R-100. Arene Candide VI}

$10,330 \pm 95$

Charcoal from Epipaleolithic layer, 3.50 to $4.50 \mathrm{~m}$ below surface. Italian Epigravettian industry.

General Comment: R-104 date, Lagozza culture, agrees well with $\mathrm{C}^{14}$ date obtained for Lagozza di Besnate, province of Varese, Lombardy, locality where this typical Upper Neolithic culture was revealed: Pi-34, $4794 \pm 90$ (Pisa II) . R-103 date, square-mouthed pots culture, is in good agreement with age of a charcoal sample from the same levels (Level 
No. 20) measured at Pisa: Pi-27, $5435 \pm 135$ (or \pm 200 ) (Tongiorgi et al., 1959; Emiliani et al., 1964). Deposits at other localities of North Italy containing square-mouthed pots, gave similar $\mathrm{C}^{14}$ dates: Isola Virginia, or Isolino, Lake of Varese, Lombardy, Pi-4, $5534 \pm 144$; Pi-38, $5326 \pm 180$ (Pisa I; Tongiorgi et al., 1959; Emiliani et al., 1964); Grotta Aisone, Valle Stura, Piedmont, $5825 \pm 75$ (Rome III). R-102 date, similar to R-103 date, seems somewhat young, though there is no convincing archaeological reason for holding quadrilobate-mouthed pots to be much older than square-mouthed ones. However, partial mixing in the deposit itself with charcoal of Levels 19-16 might be postulated. On the other hand, the age of ca. $6500 \mathrm{yr}$ attributed by others to quadrilobate-mouthed pots is perhaps too old: $6450 \pm 25$ (Emiliani et al, 1964) ; Pi-27b, $6487 \pm$ 175 (Tongiorgi et al., 1959). This latter dating refers to Level 25 which in actual fact belongs to Lower Neolithic containing printed pottery and suspected of being mixed to some extent with overlying strata (Tongiorgi et al., 1959). R-101 date, Early Neolithic, printed pottery (Levels 25-26), can be compared with Pi-27b. R-100 age agrees well with date expected for the Epigravettian industry of the layer.

\section{Grotta del Santuario della Madonna series}

Excavation of Grotta del Santuario della Madonna deposit at foot of Mt. Vingiolo in village of Praia a Mare on Tyrrhenian coast of Calabria, $297.9 \mathrm{~km}$ along state road No. 18 (Tirrena Inferiore), province of Cosenza, Calabria (39 $53^{\prime} 43^{\prime \prime} \mathrm{N}$ Lat, $15^{\circ} 47^{\prime} 11^{\prime \prime} \mathrm{E}$ Long, ca. $52 \mathrm{~m}$ above sealevel) was begun in 1959-1960 by the late A. C. Blanc, Ist. Italiano di Paleontologia Umana, and L. Cardini (Blanc and Cardini, 1957, 1958-61; Blanc et al., 1958-61) and continued in 1962-65 by L. Cardini, who coll. samples 1962-63 and subm. Dec. 1962-April 1965. Through the deposit excavated hitherto, $10.30 \mathrm{~m}$ thick, ten archaeological layers have been identified containing pottery, flint implements, charcoal, bones of domestic and wild animals and mollusc shells, food refuse. From top downward: I, Roman period; II, Middle Bronze Age, Apennines culture; III, Eneolithic, Piano Conte culture; IV, Culture not yet defined; V, Late Neolithic, Diana culture; Middle Neolithic: VI, 3rd phase, Serra d'Alto culture; VII, 2nd phase, Capri culture; VIII, lst phase, printed pottery painted with red bands; IX, Mesolithic; X, Upper Paleolithic, Gravettian industry (Tinè, 1965; Cardini and Cassoli, 1966; Cardini, Cassoli and Biddittu, 1966; Cardini, Taschini and Cassoli, 1966). Samples dated belong to IV, IX, and $\mathrm{X}$ layers.

\section{R-189. Grotta della Madonna IV}

Charcoal from sections $20-25$ of Layer IV, 2.70 to $3.30 \mathrm{~m}$ below surface. Undefined cultural elements probably of alien origin, beneath Piano Conte culture; bones of domestic animals. 
R-188. Grotta della Madonna IXa

Charred bones from middle level of Layer IX, sections 45-46, 5.10 to $5.30 \mathrm{~m}$ below surface, Mesolithic. This layer, $60 \mathrm{~m}$ thick, contains coarse flint implements and scarce bone industry; only bones of wild holocenic animals were found together with numerous shells of marine (Patella, Trochus) and fresh water molluscs, (Helix ligata), food refuse.

\section{R-187. Grotta della Madonna IXb}

$\mathbf{8 7 3 5} \pm \mathbf{8 0}$ 6785 B.C.

\section{R-187 $\alpha$. Grotta della Madonna IXb}

$8875 \pm 85$

Charcoal found in Layer IX, Mesolithic, together with charred bones sample R-188. Sample R-187 was given only standard pre-treatment by dilute $\mathrm{HCl}$; sample $\mathrm{R}-187 \alpha$ is the insoluble residue of an additional leaching with $6 \% \mathrm{NH}_{4} \mathrm{OH}$. Difference between two ages is not very significant.

\section{R-186. Grotta della Madonna Xa}

$$
10,030 \pm 90
$$

Charred bones of middle level of Layer $\mathrm{X}$, sections 57-58, 6.30 to $6.50 \mathrm{~m}$ below surface. The layer, $1.70 \mathrm{~m}$ thick, contains an Upper Paleolithic industry of Gravettian type, wild pleistocenic fauna with extinct species together with numerous shells of fresh water (Helix ligata) and scarce marine molluscs.

\section{R-185. Grotta della Madonna $\mathrm{Xl}_{\mathrm{b}}$}

$10,120 \pm 70$

Charcoal found in Layer X, Upper Paleolithic, together with charred bones R-186.

General Comment: R-189 date suggests attribution of undefined industry in Layer IV to Late Neolithic. R-188, R-187 and R-187 $\alpha$ dates (Layer IX) and R-186 and R-185 dates (Layer X) agree with the type of industry at these levels. Furthermore for each level dates of charcoal and charred bones are in good agreement. As regard charred bones, material for dating purposes was accurately chosen; after careful washing, the bones' mineral components were completely destroyed by treatment with dilute $\mathrm{HCl}$, the residual blackish matter being wholly soluble by $6 \%$ $\mathrm{NH}_{4} \mathrm{OH}$. Dating of other layers of deposit is being carried out.

\section{Grotta del Romito series}

Charcoal from Grotta del Romito deposit near Papasidero, $51.6 \mathrm{~km}$ W Castrovillari, province of Cosenza, Calabria $\left(39^{\circ} 52^{\prime} 12^{\prime \prime} \mathrm{N}\right.$ Lat, $15^{\circ}$ 54' 23" E Long). Coll. 1963-1964 and subm. January 1965 by P. Graziosi, President of Ist. Italiano di Preistoria e Protostoria. In 1961 a fine engraving of a bull together with others of a paleolithic type were found on a block of half-buried limestone in rock shelter deposit at entrance 
of cave (Graziosi, 1961, 1962a, 1962b, 1962c, 1964a). In 1963 and 1964 systernatic excavation of deposit in both cave and shelter carried out by the Ist. Italiano di Preistoria e Protostoria with the collaboration of Soprintendenza alle Antichità della Calabria brought to light (a) upper layers with pottery datable, upon a first examination, to Middle and Late Neolithic and (b) lower layers devoid of pottery with Upper Paleolithic or Epipaleolithic industries, perhaps of an Epigravettian type. In these layers (b), moreover, four buried human skeletons were found (Graziosi, 1963, 1964b).

\section{R-223. Romito I}

$6420 \pm 70$

C.harcoal from upper layers with Neolithic pottery.

\section{R-221. Romito II}

$10,960 \pm 350$

9010 B.C. industry.

Charcoal from lower layers with Upper Paleolithic or Epipaleolithic General Comment: respective dates obtained can agree with the type of industry or pottery found in the layers.

\section{Arslantepe series \\ B. Turkey}

In 1961, 1962 and 1964 an Italian Archaeol. Mission (Head: P. Meriggi, Univ. of Pavia; Director of excavations: S. M. Puglisi, Ist. di Paletnologia, Univ. of Rome), sponsored by the Centro Italiano per le Antichità e la Storia dell'Arte del Vicino Oriente, carried out excavations of the hïyük of Arslantepe near the city of Malatya, Anatolia, Turkey (38 $21^{\prime} \mathrm{N}$ Lat, $38^{\circ} 22^{\prime} \mathrm{E}$ Long). The hüyük of Arslantepe is an artificial hill $30 \mathrm{~m}$ high mainly formed of the accumulating remains of walls and buildings belonging to the super-imposed ancient Hittite cities of Malatya and of a successive Roman-Byzantine settlement. Digging has brought to light the following archaeological levels: I, Roman-Byzantine level; II, a transitional level with features that are not well defined; III, IV, held to be, respectively, neo-Hittite and Hittite-Imperial levels; V, Early Bronze Age; VI, Late Chalcolithic. In addition, surface pottery finds are proof of an Islamic settlement (Puglisi, 1962a, 1962b, 1964a, 1964b, 1965). Samples submitted to our lab. belong to intermediate levels.

\section{R-214. Arslantepe C 1}

$$
\begin{gathered}
2835 \pm 70 \\
885 \text { B.c. } \\
2795 \pm 60 \\
845 \text { B.C. }
\end{gathered}
$$

R-214 $\beta$. Arslantepe C 1

Charred wood from area of Imperial Gate, C 1 of excavation map. Coll. 1964 and subm. Oct. 1964 by E. Castaldi, Ist. di Paletnologia, Univ. of Rome. Wood belonged to a destruction level caused by fire covering ruined masonry of a monumental gate attributed, on basis of archaeol- 
ogical data, to Hittite-Imperial period (16th-12th centuries B.C.). Further archaeological evidence indicates that when fire broke out gate was already ruined and despoiled (see Puglisi, 1965, p. 122). The Imperial Gate underlies the so-called Gate of the Lions belonging to enclosure wall of the neo-Hittite citadel unearthed during previous excavations and now destroyed (Delaporte, 1940). R-214 was given only dilute $\mathrm{HCl}$ pre-treatment; R-214 $\beta$ represents the abundant humic fraction of charcoal separated through additional leaching by $6 \% \mathrm{NH}_{4} \mathrm{OH}$ and precipitated again by dilute $\mathrm{HCl}$. Difference between R-214 and R-214 $\beta$ dates is not significant and shows that sample was not contaminated, as suspected.

\section{R-218. Arslantepe B2 IIIc}

$2895 \pm 60$

R-219. Arslantepe B2 IVc

945 B.C.

R-219 $\beta$. Arslantepe B2 IV

$2655 \pm 70$

705 B.c.

Charcoal from levels of dwellings in E Area B2, IIIb and IVc, of excavation map. Coll. 1964 and subm. Oct. 1964 by A. Palmieri, Ist. di Paletnologia, Univ. of Rome. Site is outside citadel walls and stratigraphy is somewhat deranged since foundations of these buildings have altered original arrangement of the hüyük, cutting through previous deposits. As for R-214 sample, R-219 and R-219 $\beta$ (humic fraction) dates show that sample was not contaminated as suspected.

General Comment: R-214 date, younger than age attributed to Imperial Gate, confirms Puglisi's view, quoted above, that fire occurred when the gate was already in ruins. R-218 and R-219 dates are similar and give a first indication of age for an uncertain level in the eastern side of the hüyük.

Various archaeological mounds scattered throughout Turkey have so far been dated through the systematic work carried out by the Univ. of Pennsylvania Lab. (see Pennsylvania III, p. 46-47; Pennsylvania V, p. 145-146; Pennsylvania VIII, p. 191-194). The Hacilar site was dated also at British Mus. Lab. (see British Museum II, p. 29-30; British Museum IV, p. 107-108). First dates for Turkey, Alhisar site, were measured at Chicago (Chicago I, C-115 and C-183).

\section{Afghanistan}

Sponsored by IsMEO (Ist. Italiano per il Medio ed Estremo Oriente), the Italian Archaeol. Mission at Samangan, Afghanistan, has, since 1961 , been carrying out researches and excavations in the archaeological area of Hazār Sum Valley, $16 \mathrm{~km}$ NW Samangan (= Aibaq), province of Mazar-i-Sharif, North Afghanistan (ca. $36^{\circ} 15^{\prime} \mathrm{N}$ Lat, $68^{\circ} 05^{\prime} \mathrm{E}$ Long). These were entrusted by G. Tucci, President of IsMEO and Head of Italian Archaeol. Missions IsMEO in Asia, to S. M. Puglisi. Abundant 
finds of stone implements prove valley was inhabited by Paleolithic and Neolithic peoples who found refuge in the very numerous rock shelters and caves bordering the valley (Hazār Sum $=$ thousand caves). Hazār Sum site consists of a vast and complex archaeological area of urban type containing three different form of constructions: characteristic megalithic monuments, constructions with dry walls, and dwellings hewn out of the rock (cave dwellings) . Relationship and chronology of air buildings and cave-dwellings have not been well explained; all seem to belong to various historic peoples. On the remains of these preceding civilizations from 7th century A.D. onwards, Islamic peoples everywhere built their own buildings in mud bricks, the location of which is shown today by numerous so-called "Islamic mounds" formed from their ruins (Puglisi, 1963; Castaldi, 1963). As Islamic center, Hazār Sum reached its maximum importance as a junction on the old caravan route in Samanid age (10th century A.D.), as archaeological finds have confirmed.

\section{Hazāı Sum, Islamic layers series}

Charcoal from Islamic layers in F 7-8 area of Hazār Sum Map (see Puglisi, 1963, fig. 9) . Coll. 1963 and subm. 1964 by E. Castaldi.

R-208. Hazār Sum, Islamic Layer II

$1155 \pm 40$

Charcoal from the upper Layer II with numerous islamic pottery.

\section{R-212. Hazār Sum, Islamic Layer IV A.D. 1025}

Charcoal from lower Layer IV, beneath barren Layer III, with scanty potsherds showing different characteristics from upper islamic pottery.

\section{R-213. Hazār Sum, Islamic Layer IVa}

$915 \pm 45$

Charcoal from another portion of same Layer IV.

General Comment: after pre-treatment by dilute $\mathrm{HCl}$, an additional leaching with $6 \% \mathrm{NH}_{4} \mathrm{OH}$ was not deemed necessary since a separate test showed that all charcoal of the Hazär Sum site was devoid of humic acids. R-208 date agrees with expected Islamic age. R-212 and R-213 dates proved too late and confirm, as suspected, that layer was altered and material mixed with upper one (surface Layer I).

\section{Hazāır Sum, funeral cave series}

Charcoal from deposit of a cave in F 7-8 area of Hazār Sum map (see Puglisi, 1963, fig. 9). Coll. 1963 and subm. Oct. 1964 by E. Castaldi. Access to this small underground cave is by way of a corridor with steps. At bottom of deposit, separated from overlying strata by layer of stones, a human skeleton was found, hence name given to the cave. Charcoal comes from upper part of deposit that represents discarded material assumed to be Islamic. 
R-211. Hazār Sum, funeral cave 1

Charcoal from deposit inside cave above layer of stones covering skeleton.

A.D. 1075

R-210. Hazār Sum, funeral cave 2

$680 \pm 80$

Charcoal from part of deposit that filled the corridor of cave.

General Comment: R-211 date confirms attribution of this level of deposit to Islamic period; R-210 date shows that the filling-in of the cave continued till more recent times.

So far in Afghanistan territory there have been few $\mathrm{C}^{14}$ dates. Two notable archaeological sites have been dated at Hannover Lab: a) Chari-Mir, a prehistoric site in North Afghanistan on roughly the same lat. as, and not too far W of, (66 $46^{\circ} 5^{\prime}$ E Long) Hazār Sum; b) Quala Shaharak, an Islamic settlement in Central Afghanistan whose age agrees with that obtained for Islamic period of Hazār Sum (Hannover III, p. 263-264) . Furthermore the prehistoric site of Mundigak prov. of Kandahar, Bronze age, was dated at Chicago (Chicago IV, C-815) and age of a Paleolithic shelter at Kala Kamar was measured at USGS Lab. (USGS III, W-224, 226).

\section{Pakistan}

In 1956, the Italian Archaeol. Mission in Pakistan, sponsored by IsMEO and entrusted by G. Tucci to D. Faccenna, Head of Mus. of Oriental Art in Rome, began archaeological campaigns in state of Swat, W Pakistan, following an agreement with Dept. of Archaeol. of Pakistan. Swat is a region of great archaeological importance rich in extensive remains of past civilizations. Excavations by the Italian Mission have so far brought to light urban settlements, necropolises and Buddhist sacred sites (Buddhist Stupas). Radiocarbon dates are of great interest for these finds, since archaeological evidence is often scarce or of slight significance. So far dates that follow are the first for Swat.

\section{R-194. Butkara II}

$2425 \pm 40$

475 B.c.

Burnt human bones from seven cremation tombs of pre-Buddhist necropolis of Butkara II on left bank of Jāmbīl River $1.5 \mathrm{~km}$ upstream from Mingora, Swat, Pakistan (ca. $34^{\circ} 44^{\prime} \mathrm{N}$ Lat, $72^{\circ} 20^{\prime} \mathrm{E}$ Long). Coll. 1960-1961 by M. Taddei, Director of Butkara excavation, and subm. May 1964 by D. Faccenna, Head of Italian Archaeol. Mission in Pakistan, on behalf of G. Tucci. Excavated graveyard is only part of necropolis. Altogether, 48 cremation and inhumation tombs were found, all belonging to same period. In cremation tombs burnt bones, reduced to tiny pieces, were placed together with grave goods in a kind of terracotta funerary jar covered with a lid. Both in cremation and inhumation tombs handsome pottery with offerings and bronze objects were found. 
Part of necropolis area was later occupied by a Buddhist sanctuary (Silvi Antonini, 1963; Faccenna, 1964). Comment: bits of bones were carefully chosen and their mineral components were completely destroyed by treatment with dilute $\mathrm{HCl}$; in this case black residual matter was insoluble in $6 \% \mathrm{NH}_{4} \mathrm{OH}$. Date obtained agree with presumed age of necropolis that is believed to belong to Iron age.

\section{Barama I series}

Charcoal from Barama I settlement in a fluvial terrace on right side of Jämbīl River $0.5 \mathrm{~km}$ SE Mingora, Swat, Pakistan (ca. $34^{\circ} 44^{\prime} \mathrm{N}$ Lat, $72^{\circ} 20^{\prime}$ E Long). Coll. 1963 and subm. May 1964 by D. Faccenna on behalf of G. Tucci. The 1963 excavation campaign brought to light a portion of the settlement and clearly revealed five main periods of reconstruction of the buildings which are set one above the other. Beneath them another level with evidence of human habitation, probably a hutsettlement (6th period) which rests directly on clayey soil of the terrace (Faccenna, 1964-65).

\section{R.195. Barama I 5a}

$2320 \pm 45$

Fragments of charcoal from Trench I beneath the superimposed buildings of Period 1-4 in Stratum 5a, belonging to Floor P. 4a, and consisting of potsherds, stones, rubble and similar discarded material.

\section{R.196. Barama I 8}

$2585 \pm 80$

Fragments of charcoal from Trench $\mathrm{I}$ in the filling of one of small pits (Pit 2) cut into clayey soil beneath lower human settlement. Filling consists of loose earth containing a mixture of floury stuff, particles of charcoal, chaff and potsherds. Pits seem to suggest erection of huts.

General Comment: dates of R-195 and R-196 give a first indication of age for two different periods of this settlement; they are consistent and seem to agree with expected age.

\section{GEOLOGIC SAMPLES}
Alban Hills series
A. Italy
Wood embedded in "peperino" of Albano crater, from $\mathrm{N}$ slope of Albano Lake along road leading to lake shore, $24.5 \mathrm{~km}$ SE of Rome $\left(41^{\circ}\right.$ $45^{\prime} 40^{\prime \prime}$ N Lat, $12^{\circ} 99^{\prime} 38^{\prime \prime}$ E Long). R-135 and R-135 $\alpha$ represent a branch of a tree trunk brought to light in 1959 by road works; it was consigned at this time to M. Tofini and subm. 1960 by him. R-135A, R-135B and R-135C are fragments of wood coll. later in same locality by M. Fornaseri and C. Cortesi, Ist. di Geochimica, Univ. of Rome, and subm. by them. R-135B was Ulmus and R-135C was Quercus ilex (id. by M. Follieri, private commun.). 
R-135. Alban Hills

R-135 $\alpha$. Alban Hills

R-135A. Alban Hills

R-135B. Alban Hills

R-135C. Alban Hills

General Comment: peperino is considered to be one of the latest volcanic products of the Alban Hill district (Sabatini, 1900; Fornaseri, Scherillo and Ventriglia, 1963). Peperino is local name for a gray granular, moreor-less coherent tuff, containing variable amount of inclusions of eruptive and sedimentary rock fragments. By correlations with sedimentary formations, oldest tuffs have been assigned to Late Riss and to Interglacial Riss/Würm. As dated tuff is younger but still too old for $\mathrm{C}^{14}$ dating, eruption of the peperino in this locality was probably Early Würm. However, wood fragments coll. 1957 by M. Fornaseri and C. Cortesi in the same peperino formation near Marino were dated at Groningen Lab. as $\mathrm{GrN}-1496,29,720 \pm 400$ (H1. DeVries, private commun., Sept. 1958). If valid, this date implies that peperino is of more than one age and was formed as late as the Early Würm-Main Würm Interstadial.

Date lists:

\section{REFERENCES}

British Museum II
British Museum IV
Chicago I
Chicago IV
Hannover III
Pennsylvania III
Pennsylvania V
Pennsylvania VIII
Pisa I
Pisa II
Rome II
Rome III
USGS III

Barker and Mackey, 1960

Barker and Mackey, 1963

Amold and Libby, 19.51

Libby, 1954

Gevh and Schneckloth, 1964

Ralph, 1959

Ralph and Stuckenrath, 1962

Stuckenrath and Ralph, 1965

Ferrara, Reinhartz, and Tongiorgi, 1959

Ferrara, Fornaca-Rinaldi, and Tongiorgi, 1961

Alessio, Bella, and Cortesi, 1964

Alessio, Bella, Bachechi, and Cortesi, 1965

Rubin and Suess, 1956

Alessio, M., Allegri, L., and Bella, F., 1960, A CO.-proportional counter of small volume and high efficiency for low level $\beta$-counting: Ricerca scientifica, v. 30, p. $1960-1962$.

Alessio, M., Bella, F., Bachechi, F., and Cortesi, C., 196.5, University of Rome carbon-14 dates III: Radiocarbon, v. 7, p. 213-222.

Alessio, M., Bella, F., and Cortesi, C., 1964, University of Rome carbon-14 dates II: Radiocarbon, v. 6, p. 77-90.

Arnold, J. R., and Libby, W. F., 1951, Radiocarbon dates: Science, v. 113, p. 111-120.

Barker, H., and Mackey, C. J., 1950, British Muscum natural radiocarbon measurements II: Am. Jour. Sci. Radioc. Supp., v. 2, p. 26-30.

1963, British Museum natural radiocarbon measurements IV: Radiocarbon, v. 5, p. 104-108.

Bella, F., and Cortesi, C., 1960, The CO-proportional counter of the carbon-14 dating Laboratory of the University of Rome: Ricerca Scientifica, v. 30, p. 1969-1977.

Bernabò Brea, L., 1946, Gli scavi nella Caverna delle Arene Candide I-Gli strati con ceramiche: Ist. di Studi Liguri, Bordighera.

1956. Gli scavi nella Caverna delle Arene Candide II-Campagna di scavo 1948-1950: Ist. di Studi Liguri, Bordighera.

Blanc, A. C., and Cardini, L., 1957. Sopralluogo al giacimento di Scalea e alle caverne di Praia a Mare (Calabria): Quaternaria, v. 4, p. 218. 
1958-61, Prospezione nei dintorni di Praia a Mare ed a Scalea (Cosenza) : Quaternaria, v. 5, p. 294-297.

Blanc, A. C., Cardini, L., Taschini, M., and Cassoli, P., 1958-61, Scavo alla Grotta della Madonna di Praia a Mare. Rinvenimento di culture appenniniche e del Neolitico Medio: Quaternaria, v. 5, p. 351-352.

Cardini, L., 1941, Ricerche paletnologiche nella Caverna delle Arene Candide (Finale Ligurc-Marina): Arch. Antrop. Etnol., v. 70, p. 110-119.

1942, Nuovi documenti sull' antichità dell' uomo in Italia; reperto umano del Paleolitico Superiore nella Caverna delle Arene Candide: Razza e Civiltà, v. 3, nos. $1-4$, p. $5-25$.

1946, Gli strati mesolitici e paleolitici della Caverna delle Arene Candide: Riv. di Studi Liguri, v. 12, nos. 1-3, p. 3-11.

1955, Scavo nelle Arene Candide (Savona): Quaternaria, v. 2, p. 277-279.

Cardini, L., and Cassoli, P., 1966, Terza campagna di scavi alla Grotta della Madonna di Praia a Mare: Quaternaria, v. 8, in press.

Cardini. L., Cassoli, P., and Biddittu, I., 1966, Quarta campagna di scavi alla Grotta della Madonna di Praia a Mare: Quaternaria, v. 8, in press.

Cardini. L., Taschini, M., and Cassoli, P., 1966, Seconda campagna di scavi alla Grotta della Madonna di Praia a Mare. Rinvenimento di culture mesolitiche e del Paleolitico Superiore: Quaternaria, v. 8, in press.

Castaldi, E., 1963, Preliminary report on the researches at Hazār Sum (Samangan) Italian archeological mission in Afghanistan: East and West, v. 14, nos. 3-4, p. $183-205$.

Delaporte, L., 1940, La Porte des Lions: Paris.

Emiliani, C., Cardini, L., Mayeda, T., McBurney, C. B. M., and Tongiorgi, E., 1964, Paleotemperature analysis of fossil shells of marine molluscs (food refuse) from the Arene Candide Cave Italy, and the Haua Fteah Cave, Cyrenaica, p. 133-156: in Craig, H., Miller, L. L., and Wasserburg, G. J., editors, Isotopic and Cosmic Chemistry: Amsterdam, North Holland Publ. Co.

Faccenna, D., 1964-65, Results of the 1963 excavation campaign at Barama I (SwatPakistan): East and West, v. 15, nos. 1-2, p. 7-23. 1964, A guide to the excavations in Swat (Pakistan) 1956-1962: Dept. of Archaeol. of Pakistan and Ist. Italiano per il Medio ed Estremo Oriente, Roma.

Ferrara, G., Reinharz, M., and Tongiorgi, E., 1959, Carbon-14 dating in Pisa: Am. Jour. Sci. Radioc. Supp., v. 1, p. 103-110.

Ferrara, G., Fornaca-Rinaldi, G., and Tongiorgi, 1961, Carbon-14 dating in Pisa-II: Radiocarbon, v. 3, p. 99-104.

Fornaseri, M., Scherillo, A., and Ventriglia, U., 1963, La regione vulcanica dei Colli Albani (Vulcano Laziale): Roma, Consiglio Nazionale delle Ricerche.

Geyh, M. A., and Schneekloth, H., 1964, Hannover radiocarbon measurements III: Racliocarbon, v. 6, p. 251-268.

Graziosi, P., 1961, Scoperte e scavi preistorici in Italia durante il 1961_Calabria: Riv. Sci. Preistoriche, v. 16, p. 259.

1962a, La scoperta di incisioni rupestri di tipo paleolitico nella Grotta del Rornito presso Papasidero in Calabria: Klcarchos, v. 4, nos. 13-14, p. 12-20. 1962b, Nuove incisioni rupestri di tipo paleolitico in Calabria: Riv. Sci. Preistoriche, v. 17, p. 139-145.

1962c, Découverte de gravures rupestres de type paleolithique dans l'abri du Romito (Italie): L'Anthropologie, v. 66, nos. 3-4, p. 262-268.

1963, Scoperte e scavi preistorici in Italia durante il 1963_Calabria: Riv. Sci. Preistoriche, v. 18 , p. 315 .

1964a, Signes lineaires paléolithiques gravés dans l'abri du Romito (Cala-

bria): Miscelánea en homenaje al Abate Henri Breuil, Barcelona, p. 457-461.

1964b, Scoperte e scavi preistorici in Italia durante il 1964-Calabria: Riv. Sci. Preistoriche, v. 19, p. 301-302.

Libby, W. F., 1954, Chicago radiocarbon dates IV: Science, v. 119, p. 135-140.

Puglisi, S. M., 1962a, Campagna di scavi a Malatya: Oriens Antiquus, v. 1, no. 1, p. $130-133$.

1962b, Excavations of the Italian Mission at Arslantepe (Malatya), season 1961: Türk Arkeol. Dergisi, v. 11, no. 2, p. 140-142.

1963, Preliminary report on the researches at Hazār Sum (Samangan):

East and West, v. 14, nos. 1-2, p. 1-8. 
1964a, Second report on the excavations at Arslantepe (Malatya): Türk Arkeol. Dergisi, v. 13, no. 1, p. 123-124.

1964b, Malatya-I: Oriens Antiquus, v. 3, p. 91-127.

1965, Terza campagna di scavi a Malatya: Oriens Antiquus, v. 4, p. 121-125.
Ralph, E. K., 1959, University of Pennsylvania radiocarbon dates III: Am. Jour. Sci Radioc. Supp., v. 1, p. 45-58.

Ralph, E. K., and Stuckenrath, R., Jr., 1962, University of Pennsylvania radiocarbon dates V: Radiocarbon, v. 4, p. 144-159.

Rubin, M., and Suess, H. E., 1956, U.S. Geological Survey radiocarbon dates III: Science, v. 123 , p. $442-448$.

Sabatini, V., 1900, I Vulcani dell' Italia centrale ed i loro prodotti. Parte I: Vulcano Laziale: Memorie descrittive della carta geologica d'Italia, v. 10, tip. Bertero, Roma.

Silvi Antonini, C., 1963, Preliminary notes on the excavation of the necropolises found in western Pakistan: East and West, v. 14, nos. 1-2, p. 13-25.

Stuckenrath, R., Jr., and Ralph, E. K., 1965, University of Pennsylvania radiocarbon dates VIII: Radiocarbon, v. 7, p. 187-199.

Tinè, S., 1965, Grotta del Santuario della Madonna_Piccola Guida della Preistoria Italiana: Firenze, 2nd ed., Sansoni, p. 146-147.

Tongiorgi, E., Radmilli, M., Rinaldi Fornaca, G., and Ferrara, G., 1959, Programma di datazioni con radiocarbonio delle culture italiane della preistoria recente in collaborazione con Ist. Italiano di Preistoria e Protostoria: Laboratorio di Geologia Nucleare, Pisa, mimeographed. 